Кузьменко О. Б., доктор економічних наук

Чорноморський державний університет ім. Петра Могили

\title{
КОНЦЕПТУАЛЬНІ ПОЛОЖЕННЯ РОЗВИТКУ РЕСУРСООЩАДНОЇ ДІЯЛЬНОСТІ АГРАРНИХ ПІДПРИЕМСТВ
}

\section{Рецензент - доктор економічних наук В. В. Горлачук}

\begin{abstract}
Обтрунтовано необхідність розвитку ресурсоощадної діяльності аграрних підприємств із використанням інновачійних технологій органічного землеробства. Запропоновано концептуальні положення такого розвитку, щзо включають: передумови та фактори ресурсоощадної діяльності підприємств; основні иілі розвитку ресурсоощадної діяльності; систему оцінки стану використання ресурсів аграрного підприсмства; механізми реалізації концептуальних положень; иільові напрями та основні завдання ресурсоощадної діяльності; очікувані результати.
\end{abstract}

Ключові слова: конщептуальні положення, ресурсоощадна діяльність, аграрні підприємства.

Постановка проблеми. Розвиток аграрного виробництва у світі та Україні в останні роки був спрямований на інтенсифікацію 3 широким використанням індустріальних технологій, що супроводжуються техногенним навантаженням та екологічними збитками. Загальний обсяг світового сільськогосподарського виробництва у порівняльних цінах у 2000 році збільшився у 5,96 разу відносно 1900 року [3]. Зростання виробництва продукції щороку становило 4,3% у розвинутих країнах і 8,4 \% у країнах, що розвиваються, й досягло за вказаний період 1690 млрд доларів. Проте незважаючи на суттєве зростання виробництва сільськогосподарської продукції, за даними Всесвітньої організації охорони здоров'я, близько 800 млн чол. у світі живуть в умовах недоїдання й голоду.

Чисельність населення Землі неухильно зростає і хоча йде освоєння території для аграрного виробництва за рахунок лісів, однак площа орних земель, що припадає на одну людину, скорочується. Водночас висока техногенність, зростання екологічного навантаження на земельні ресурси (в тому числі при виробництві культур для біопалива) зумовлюють значне зростання попиту на продукти харчування та їх подорожчання. Це означає, що Україна має скористатися такою ситуацією в своїх інтересах, активно і взаємопогоджено використовувати всю сукупність ресурсів аграрних підприємств, щоб забезпечити як власну продовольчу безпеку, так і утвердження провідного становища країни на світовому ринку сільськогосподарської продукції.

Тим часом за останні роки економічних реформ в аграрному секторі економіки динаміка розвитку агропромислового комплексу характеризується несталістю, що призвело до поглиблення диспаритету цін, зниження ефективності використання ресурсів аграрних підприємств, скорочення аграрного виробництва i розвитку негативних соціальних тенденцій на селі. У цьому зв'язку перед економічною наукою і господарською практикою виникають проблеми принципово нового характеру, що вимагають розробки концептуальної моделі та механізмів інтенсифікації використання ресурсів аграрних підприємств на основі активізації ресурсоощадної діяльності.

Аналіз основних досліджень і публікацій, у яких започатковано розв'язання проблеми. Проблеми ефективного використання і збереження аграрних ресурсів у сучасних умовах України досліджувалися такими відомими вченими: В. Г. Андрійчуком, Д. Крисановим, Г. М. Підлесецьким, О. Попокою, В. Прадуном, Н. Скурською, М. Т. Толкачем, В. М. Трегобчуком, О. В. Ульянченко, А. Е. Юзефовичем [1-3, 18, 20] та іншими. Однак негативні тенденції розвитку сільського господарства, недієвий організаційноекономічний механізм захисту земельних ресурсів, висока вартість основних і оборотних виробничих фондів, недостатнє фінансове забезпечення раціонального використання ресурсів, розбалансованість сукупної аграрної ресурсної бази визначають напрями досліджень як у теоретичному, так і в практичному плані.

Метою дослідження $є$ розробка концептуальних положень розвитку ресурсоощадної діяльності аграрних підприємств із використанням інноваційних технологій органічного землеробства.

Результати досліджень. Сучасна інтенсивна система землеробства характеризується високою енерговитратністю, активним використанням мінеральних добрив та пестицидів, які забруд- 
нюють грунт, руйнують його мікрофлору і мікрофауну, потрапляють у рослинницьку продукцію, погіршуючи ii якість. Глибока механічна обробка грунтів посилює процеси ерозії, знижує їх природну родючість. Проте зростання витрат енергоресурсів, хімічних засобів живлення та захисту рослин наблизилося до межі насиченості, не забезпечуючи пропорційного зростання урожайності культур. Враховуючи вищесказане, перспективним напрямом розвитку ресурсоощадної діяльності аграрних підприємств в Україні є використання інноваційних технологій органічного землеробства, в контексті чого роз- роблено концепційні положення такого розвитку (див. рис.). У цих положеннях на підставі принципу постійного вдосконалення враховано засади національної стратегії енерго- і ресурсозбереження (з метою максимальної відповідності їм), діючі нормативно-правові акти 3 питань ресурсоощадної діяльності (з метою забезпечення відповідності чинному законодавству), міжнародні нормативно правові документи 3 виробництва органічної продукції, синтез позитивних сторін традиційних й інноваційних технологій органічного землеробства.

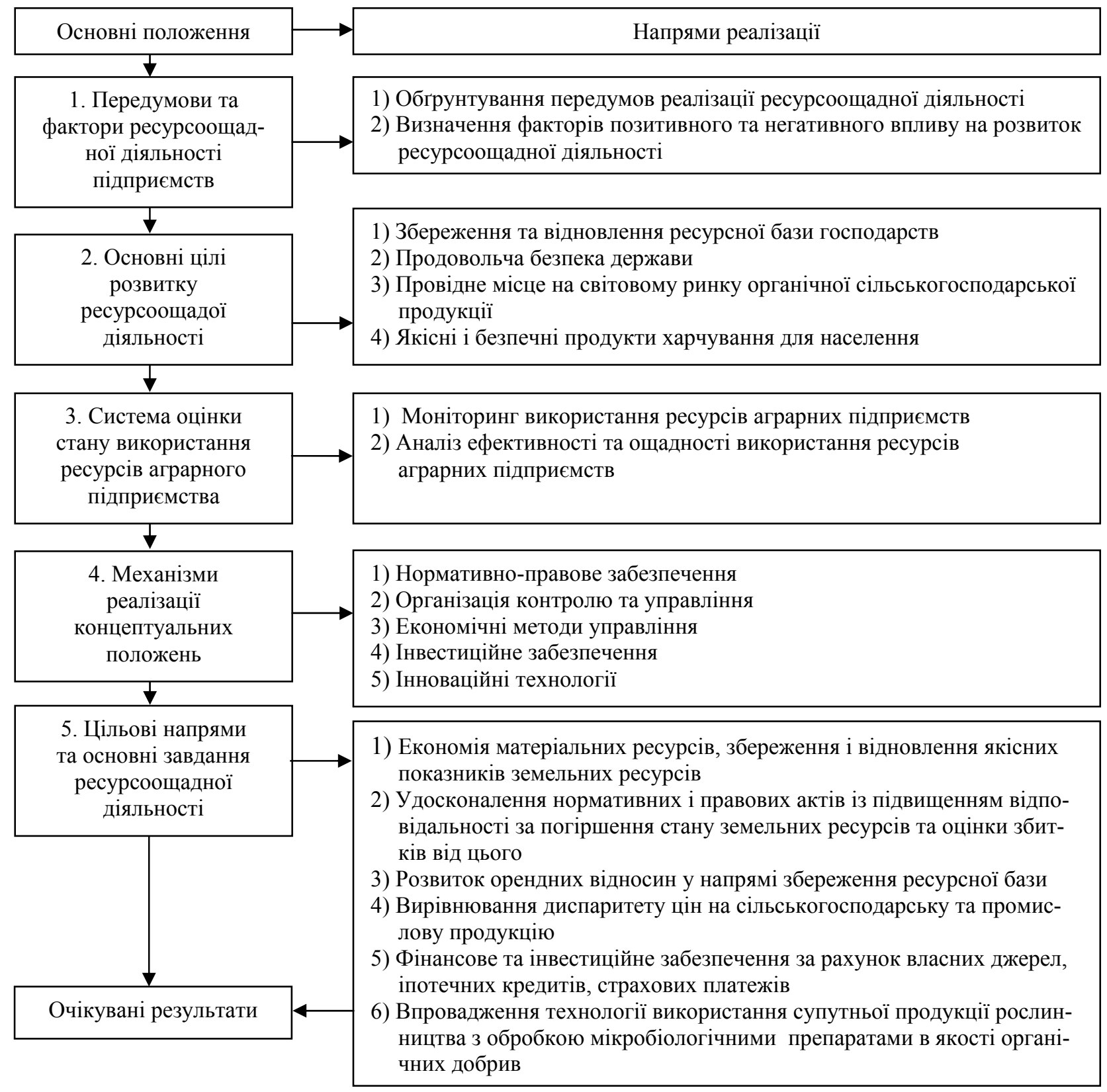

Рис. Основні концептуальні положення розвитку ресурсоощадної діяльності аграрних підприємств 
1. Передумови та фактори ресурсоощадної діяльності аграрних підприємств

Кон'юнктура світового ринку продуктів харчування спонукає аграрний сектор України розвивати виробництво в напрямі зростання обсягів продукції та підвищення іiі якості. Ці завдання можливо забезпечити на основі використання ресурсоощадних технологій, які, з одного боку, забезпечують економію матеріальних ресурсів (мінеральні добрива), а, з іншого, - відновлюють якісні характеристики земельних ресурсів аграрних підприємств, їх природну родючість. Ці технології об'єднують позитивні сторони контурномеліоративного та органічного землеробства [9].

Ресурсна база аграрних підприємств в Україні має свої особливості, які необхідно враховувати для розвитку ресурсоощадної діяльності.

До факторів негативного впливу слід віднести:

- застосування переважно екстенсивних методів збільшення обсягів виробництва;

- високий рівень господарського освоєння території;

- неможливість подальшого розширення площ сільськогосподарських угідь;

- низький рівень продуктивності в аграрних підприємствах;

- стійку тенденцію до погіршення якості грунтів у результаті дії деструктивних явищ (деградація землі);

- високий рівень забруднення грунтів у промислових регіонах;

- постійне зростання цін на матеріальні та паливо-енергетичні ресурси аграрних підприємств.

До факторів, що мають позитивний вплив, відносяться:

- наявність значного земельно-ресурсного потенціалу (високородючі грунти та великі за площею);

- наявність значного потенціалу трудових ресурсів в аграрному секторі;

- сприятлива кон'юнктура світового ринку на органічну продукцію;

- забезпеченість в достатній мірі земельними ресурсами, здатними до відновлення й самоочищення.

В Україні ще не створені в повній мірі необхідні передумови стрімкого розвитку ресурсоощадної діяльності на підставі органічного землеробства. 3 цією метою необхідно вирішити низку проблем, головними з-поміж яких є:

- розробка концепції розвитку ресурсоощадної діяльності аграрних підприємств;

- підготовка висококваліфікованих фахівців;

- якісний моніторинг ресурсної бази аграрних підприємств;

- забезпечення охорони, відтворення та відновлення земельних ресурсів;

- науково-технічне й технологічне забезпечення ресурсоощадної діяльності;

- зниження ресурсоспоживання аграрної галу$3 i$.

Водночас уже створено чимало передумов, що сприятимуть розвитку ресурсоощадної діяльності аграрних підприємств:

- вступ України до СОТ та інших світових $\mathrm{i}$ європейських структур, які дотримуються ідеології ресурсоощадної діяльності;

- наявність значного інтелектуального потенціалу аграрного сектора i перспективних розробок;

- наближення внутрішніх цін на матеріальні і паливо-енергетичні ресурси до світових.

2. Основні ичілі розвитку ресурсоощуадної діяльності:

1) Збереження i відновлення ресурсної бази аграрних господарств.

Відтворювальні процеси матеріальнотехнічних ресурсів аграрних підприємств за роки ринкових трансформацій значно погіршилися. Втричі скоротилася чисельність тракторів i зернозбиральних комбайнів [19]. Інвестиції в основний капітал скоротилися у порівняльних цінах у 10 разів [5, 19]. Основним джерелом ринкових ресурсів стали власні кошти підприємств. Чисельність зайнятих у сільському господарстві, порівняно з 1990 роком, скоротилося на 1759 тис. осіб [19]. Якісний стан земельних ресурсів погіршився за вмістом у грунтах гумусу i поживних речовин. До того ж темпи негативних тенденцій прискорилися (по Миколаївській області в 4,3 разу) [8]. У 12 разів зменшилося внесення в грунт органічних добрив і в 3,2 разу мінеральних добрив. Отже, негативні тенденції розвитку ресурсної бази аграрних підприємств зумовили необхідність активізації ресурсоощадної діяльності.

2) Продовольча безпека держави.

Самозабезпеченість України продуктами харчування, створення резервів на випадок надзвичайних ситуацій неможливі без інтенсифікації використання ресурсів аграрних підприємств, одним із елементів якої $є$ ресурсоощадна діяльність.

3) Провідне місце на світовому ринку органічної сільськогосподарської продукції.

Попит на продовольство в світі постійно зростає, в тому числі на органічні продукти харчування. Країни з розвинутою ринковою економікою надають Україні консультаційну і фінансову 
допомогу з розвитку органічного землеробства, сертифікації продукції. Наявність високоякісних земельних ресурсів, порівняно незначне їх забруднення залишками мінеральних добрив і пестицидів створюють для нашої держави сприятливі умови розвитку органічного землеробства, що, в свою чергу, забезпечується інноваційними технологіями. Україна має значний потенціал збільшення виробництва органічної продукції й комплекс передумов виходу на світовий ринок.

4) Якісні і безпечні продукти харчування для населення.

Використання пестицидів і мінеральних добрив призводить до забруднення продукції рослинництва нітратами, важкими металами, радіоактивними речовинами та ін. Це викликає зростання захворюваності населення органів шлунково-кишкового тракту, інтоксикації, онкологічних хвороб і под. Ресурсоощадна діяльність із використанням органічного землеробства підвищує якість продуктів харчування, покращує здоров'я населення.

3. Система очінки стану використання ресурсів аграрними підприємствами.

Оцінка стану використання ресурсів забезпечується як на державному рівні (моніторинг земельних ресурсів, трудових ресурсів), так і на рівні підприємства (моніторинг матеріальних, технічних ресурсів). Вдосконалення системи оцінки використання ресурсів іде по напрямах організаційних заходів (наприклад, надання проектно-технологічним центрам, «Облдержродючість» повноважень інспекції [10]), розширення інформаційної бази оцінки [13] та ін. Аналіз ефективності використання ресурсів доповнюється показниками («землеємкість» [7], коефіцієнт ефективності використання природноресурсного потенціалу тощо).

4. Механізми реалізації концептуальних положень.

Механізми реалізації забезпечуються системою нормативно-правових, організаційних, економічних, інвестиційних, технічних і технологічних засобів і заходів, спрямованих на раціональне, комплексне та економне споживання цих видів ресурсів аграрних підприємств, виходячи 3 існуючого рівня розвитку продуктивних сил, iз одночасним зменшенням антропогенного навантаження на навколишнє середовище. Ці механізми діють у комплексі, й лише об'єднання в оптимальному співвідношенні забезпечить максимальний ефект ресурсоощадної діяльності.

5. Цільові напрями та основні завдання ресурсоощадної діяльності.

Розв'язання проблеми активізації ресурсо- ощадної діяльності аграрних підприємств здійснюватиметься шляхом реалізації концептуальних положень за такими напрямами:

1) Економія на використанні мінеральних добрив, пестицидів, паливно-мастильних матеріалів. Збереження і відновлення технічних характеристик силових машин, комбайнів, транспорту, засобів механізації й автоматизації, будівель споруд та ін. Відтворення в грунтах вмісту гумусу, поживних речовин;

2) Вдосконалення нормативно-правової бази 3 підвищення відповідальності адекватно заподіяної шкоди стану земельних ресурсів шляхом регламентації порушень проектів землеустрою [17], уточненню оцінки збитків від погіршення стану земельних ресурсів аграрних підприємств на основі затрат, необхідних на відновлення характеристик [13] та ін.

3) Розвиток орендних відносин щодо підтримки великотоварних підприємств через стимулювання створення консолідованих об'єднань власників земельних паїв. Збільшення орендної плати з урахуванням того, що іiі частина піде на заходи ресурсозбереження [14];

4) Вирівнювання диспаритету цін на сільськогосподарську та промислову продукцію держава створює встановленням стандарту середньої норми прибутку для аграрного виробництва на рівні промисловості. Ціноутворення аграрної продукції здійснюється на підставі собівартості продукції та ціни землі [15]. Держава підтримує паритет цін, встановлюючи для аграрних підприємств лімітований обсяг продажу по гарантованій форвардній ціні. Вилучення 3 користування деградованих та малопродуктивних земель, з одного боку, буде згладжувати диспаритет, а з іншого, - радикальний захід збереження земельних ресурсів.

5) Розвиток фінансового та інвестиційного забезпечення аграрних підприємств за рахунок іпотечного кредитування під заставу земельних ділянок в умовах повноцінного ринку землі [4], оптимізації амортизаційних відрахувань капітальних витрат на поліпшення земель [6], розвитку страхування ресурсів аграрних підприємств [16];

6) Впровадження технологій використання супутньої продукції рослинництва 3 обробкою мікробіологічними препаратами в якості органічного добрива дає змогу аграрним підприємствам заощаджувати кошти на зменшенні застосування мінеральних добрив, відтворювати якісний стан земельних ресурсів, отримувати додатковий урожай внаслідок зростання вмісту в грунті поживних речовин $[11,12]$. 
6. Очікувані результати.

У результаті виконання концептуальних положень передбачається:

- розв'язати завдання аграрної реформи в напрямі підвищення ефективності використання ресурсів аграрних підприємств;

- здійснити раціоналізацію аграрного ресурсокористування та зробити аграрні підприємства інвестиційно привабливими;

- збільшити фінансування ресурсоощадної діяльності з усіх можливих джерел;

\section{БІБЛІОГРАФІЯ}

1. Андрійчук В. Г. Ефективність діяльності аграрних підприємств: теорія, методика, аналіз / В. Г. Андрійчук: монографія, 2-е вид. (без змін). - К. : КНЕУ, 2006. - 292 с.

2. Відтворення та ефективне використання ресурсного потенціалу АПК: теоретичні і практичні аспекти / В. Трегобчук, А. Юзефович, Д. Крисанов [та ін.] : відпов. ред. акад. УААН В. М. Трегобчук. - К. : Інститут економіки НАНУ, 2003. - 259 c.

3. Мировая экономика: глобальные тенденции за 100 лет. - М. : Экономист, 2003. - С. 590-592.

4. Кузьменко О. Б. Удосконалення грошової оцінки сільськогосподарських земель / О. Б. Кузьменко // Збірник наукових праць Донецького університету управління «Маркетингова i логістична технологія управління». - T. VI. - Вип. 54 : Серія «Економіка». - Донецьк : ДонДУУ, 2005. C. 54-60.

5. Ковальчук T. Проблема ефективного землекористування в Україні / Т. Ковальчук, О. Розинка // Банківська справа. - 2006. - №1. - С. 36-46.

6. Кузьменко О. Б. Фінансове забезпечення відтворення земель сільськогосподарського призначення / О.Б.Кузьменко // Вісник аграрної науки Причорномор'я : науково-теоретичний фаховий журнал Миколаївського державного аграрного університету. - Випуск 2(34). - Миколаїв : Вид-во МДАУ, 2006. - С. 59-63.

7. Кузьменко О. Б. Теоретико-методологічні питання земель сільськогосподарського призначення як засобу праці / О. Б. Кузьменко // Наукові праці : науково-методичний журнал. - Т. 51. Вип. 38 : Економічні науки. - Миколаїв : Вид-во МДГУ ім. П. Могили, 2006. - С. 49-52.

8. Кузьменко О. Б. Проблема збереження і відтворення гумусу в грунтах Миколаївської області / О. Б. Кузьменко // Наукові праці : науковометодичний журнал. - Т. 81. - Вип. 68 : Екологія. Сучасний стан родючості грунтів та шляхи їі збереження. - Миколаїв : Вид-во МДГУ ім. П. Мо-
- впровадити інноваційні технології ресурсоощадної діяльності аграрних підприємств.

Висновки. Перспективним напрямом розвитку ресурсоощадної діяльності аграрних підприємств в Україні $€$ використання інноваційних технологій органічного землеробства. Концептуальні положення такого розвитку надають можливість на підставі нормативно-правового, організаційного, інноваційно-технологічного, фінансового забезпечення створити умови для його реалізації.

гили, 2008. - С. 95-98.

9. Кузьменко О. Б. Сучасні напрями формування екологобезпечного землекористування / О. Б. Кузьменко // Проблеми і перспективи інноваційного розвитку економіки України: Матеріали Міжнар. наук.-практ. конф. - Дніпропетровськ: Національний гірничий університет, 2009. - Т. 1. - C. 203-204.

10. Кузьменко О. Б. Розвиток організаційноекономічного механізму збереження природних властивостей грунтів / О. Б. Кузьменко // Проблеми формування та оцінки ефективності функціонування сучасних землегосподарських систем : Матеріали Міжнар. наук. конф., м. Київ, 28 жовтня 2010 р. / Рада по вивченню продуктивних сил України НАН України. - К. : РВПС України НАН України, 2010. - С. 143-145.

11. Кузьменко О. Б. Використання мікробіологгічних препаратів для розкладання нетоварної продукції зернових культур / О. Б. Кузьменко // Наукові праці : науково-методичний журнал. Т. 132. - Вип. 119 : Серія «Екологія». - Миколаїв: Вид-во ЧДУ ім. Петра Могили, 2010. - С. 5054.

12. Кузьменко О. Б. Вплив мікробіологічних препаратів серії ЕM на розкладання нетоварної частини урожаю зернових культур для відновлення мікроелементного складу грунту / О. Б. Кузьменко // Вісник Полтавської державної аграрної академії. - №3. - Полтава : Вид-во ПДАА, 2010. C. 44-49.

13. Кузьменко О. Б. Методичні рекомендації щодо оцінки збитків внаслідок погіршення якісного стану грунтів під час оренди / О. Б. Кузьменко // Економіка АПК. - 2011. - №1. - С. 61-64.

14. Кузьменко О. Б. Ресурсоощадна діяльність аграрних підприємств в умовах інтенсифікації використання земельних ресурсів: теорія, методологія, практика: монографія / О.Б. Кузьменко. - Миколаїв : Вид-во ЧДУ ім. Петра Могили, 2011. -357 c. 
15. Кузьменко О. Б. Диспаритет цін як фактор обмеження розвитку екологічно безпечного землекористування / О.Б. Кузьменко // Сборник научных трудов по материалам Международной научно-практической конференции «Современные направления теоретических и прикладных исследований - 2011». - Т. 13 : Серия «Экономика». - Одесса : Черноморье, 2011. - С. 86-95. 16. Кузьменко О. Б. Розвиток організаційноекономічного забезпечення страхування якісного стану земельних ділянок / О. Б. Кузьменко // Вісник Полтавської державної аграрної академії. -№1. - Полтава : Вид-во ПДАА, 2011. - С. 112116.

17. Кузьменко О. Б. Економічний механізм адміністративної відповідальності за недотримання проектів землеустрою сільськогосподарських землекористувань / О. Б. Кузьменко // Бізнеснавігатор: науково-виробничий журнал. - №1(22). - Херсон : Вид-во МУБіП, 2011. - С. 160-166.

18. Підлісецький Г. М. Підвищення ефективності використання ресурсного потенціалу аграрного сектора / Г. М. Підлісецький, М. І. Толкач // Економіка АПК. - К. : НАН, 2008. - №5. - С. 6566.

19. Сільське господарство України за 2009 рік / [ред. Ю. М. Остапчука]. - Державний комітет статистики України. - ДП «Інформаційноаналітичне агентство». - К., 2010. -386 с.

20. Ульянченко О. В. Формування та використання ресурсного потенціалу в аграрному сектоpi / О. В. Ульянченко: монографія. - Х., 2006. $357 \mathrm{c}$. 